\title{
Chapter 4 \\ Locating Human Rights in the Cultural Competence Context
}

\author{
Michael Johnston
}

\section{Introduction}

In settler-colonial countries, where European powers have forcibly established themselves on top of pre-existing Indigenous societies, formally recognising Indigenous sovereignty and supporting Indigenous self-determination should be central to the philosophy and praxis of cultural competence. Australian higher education institutions have taken important steps in addressing systemic Indigenous disadvantage. While cultural competence attempts to foster social and emotional wellbeing and encourages critical self-reflection in order to understand how one's beliefs and attitudes are formed by culture, in order to create behavioural change, Indigenous sovereignty as a central aspect to cultural competence in Australian higher education remains neglected. When framed in the context of the relationship between the settler-state and Aboriginal and Torres Strait Islander peoples, particular social patterns, such as the stark inequality in access to higher education, appear as a consequence of the failure of educational institutions to respond to the ongoing impact of colonisation. In order to address Indigenous disadvantage, public universities that are committed to engaging with the field of cultural competence must take seriously their complicity in the maintenance of settler-colonial institutions that generate and distribute knowledge and opportunity in society. A deeper, multilayered knowledge and understanding of the role that Indigenous sovereignty and national identity play in settler-colonial institutions, and recognising the social responsibility to facilitate Indigenous self-determination, must be embedded in cultural competence philosophy and praxis in Australia.

Developing a nuanced understanding of Indigenous sovereignty and national identity are key steps in coming to understand one's own cultural values and their implications for making respectful, reflective, reasoned choices on the journey towards

M. Johnston ( $\varangle)$

The University of Sydney, Sydney, Australia

e-mail: mikeyjohnston28@gmail.com 
cultural competence. Cultural competence is a set of intercultural communication skills, attitudes, behaviours and policies, which emerged in the late 1980s in the United States of America (US) in order to address inequalities between ethnic and linguistically diverse groups in the health care setting (Cross et al., 1989). Inequalities in health outcomes were identified as having been the result of discrimination, poverty and isolation; for example, First Nations peoples living in remote areas were receiving poor health services (Cross et al., 1989). Those advocating on behalf of groups and individuals experiencing structural disadvantage criticised the US government and the health care system for failing to meet their international human rights obligations under the Universal Declaration of Human Rights (UN General Assembly, 1948). Specifically, the Declaration identifies the right to health which is a "fundamental part of our human rights and of our understanding of a life in dignity," thereby grounding cultural competence in a human rights framework, and establishing the need for institutional change (World Health Organisation n.d., p. 1). Since the 1980s, cultural competence has expanded into other fields - such as higher education, government, business and social sciences_-in the US and other settler-colonial countries including Australia.

Cultural competence is a developing paradigm aimed at increasing understanding and effective communication skills in intercultural settings and has been taken up in a variety of contexts. In recent years, Australian universities have attempted to grapple with disparities in access to higher education between Indigenous and nonIndigenous people, while aiming to integrate Indigenous Knowledges (IKs) across disciplines (Battiste, 2005; Rigney, 1999, 2017; Riley, Howard-Wagner, Mooney, \& Kutay, 2013; Sherwood et al., 2011). As the peak body representing the higher education sector in Australia, Universities Australia (UA) recommends the implementation of cultural competence which it defines as "student and staff knowledge and understanding of Indigenous Australian cultures, histories and contemporary realities and awareness of Indigenous protocols, combined with the proficiency to engage and work effectively in Indigenous contexts congruent to the expectations of Indigenous Australian peoples" (UA, 2011). Accordingly, Wingara Mura-Bunga Barrabugu, The University of Sydney's Aboriginal and Torres Strait Islander integrated strategy (2012), sets out a whole of organisation approach to the development and integration of Indigenous cultures, pedagogies and epistemologies within the University, including the establishment of cultural competence as a graduate quality, and the creation of a National Centre for Cultural Competence (NCCC).

Established in 2014, the NCCC's mission is to be a thought leader in cultural competence philosophy and praxis, which includes challenging the prevailing assumptions about power, privilege and racism which are embedded within Australian public institutions such as universities, health organisations and government bodies (Sherwood \& Russell-Mundine, 2017). In order to achieve this mission, the NCCC is guided by a human rights framework that privileges "Indigenous ways of knowing, being and doing" and emphasises critical self-reflection at both interpersonal and organisational levels (Sherwood, 2010). The term "human rights" appears throughout the seminal chapter, "How We Do Business: Setting the Agenda for 
Cultural Competence at The University of Sydney" (2017) by Professor Juanita Sherwood and Dr. Gabrielle Russell from the NCCC. It appears more than 40 times in the foundational text on the topic of cultural competence in Australian higher education, the National Best Practice Framework for Indigenous Cultural Competency (2011). However, outside of statements about discrimination, the relationship between human rights and cultural competence remains opaque in these core cultural competence texts, requiring further investigation and analysis. This chapter explores and clarifies what "human rights" means in the context of cultural competence in Australia, based on Indigenous sovereignty and its implications for non-Indigenous people making respectful, reflective, reasoned choices to support Indigenous self-determination.

\section{Indigenous Sovereignty}

Indigenous sovereignty is intrinsic to Indigenous people and the lands to which they belong and is a vital concept to understand in the journey towards cultural competence. This chapter explores approaches to understanding Indigenous sovereignty of scholars from several English language settler-colonial nations: the US, New Zealand, Canada and Australia. In order to have understandings of "Indigenous Australian cultures, histories and contemporary realities and awareness of Indigenous protocols, combined with the proficiency to engage and work effectively in Indigenous contexts congruent to the expectations of Indigenous Australian peoples," universities must formally recognise Indigenous sovereignty and work towards the facilitation of Indigenous self-determination (UA, 2011). This requires the recognition of Indigenous sovereignty in University policies, public spaces and curricula, and an acknowledgement of the impact settler-colonialism has had on Indigenous people's ability to determine their own affairs, through a commitment to respecting, supporting and promoting Indigenous people and their cultural autonomy. In this context, sovereignty can be seen as a European concept that is intrinsic to Indigenous people, and which Indigenous people have asserted as a political strategy since their lands were invaded and forcibly colonised by European powers. This is not to suggest that Indigenous people did not have sovereignty before colonisation; only that it exists within Indigenous epistemological, ontological and axiological realms that are distinct from — and yet can be located within — settler-colonial legal frameworks. Indigenous people's human right to self-determination has come about as a result of the existence of Indigenous sovereignty and ongoing resistance to settler-colonialism.

The recognition of Indigenous sovereignty in Australia requires acknowledgement of, and respect for, the heterogeneity of Aboriginal and Torres Strait Islander national, cultural and linguistic diversity. As an indication of Indigenous cultural diversity prior to colonisation, 29 clan groups make up the Eora nation in the Sydney region alone, while there are over 250 Aboriginal and Torres Strait Islander nations across Australia, each defined by distinct boundaries, spiritual systems, customs, laws, traditions, artistic practices and languages (Hinkson \& Harris, 2010). In the years 
following 1788, the Eora nation bore the brunt of the British invasion which eventually extended across the entire continent, the ongoing impact of which continues to maintain Indigenous disadvantage. Sherwood states that within this context, the original violation of Indigenous sovereignty "was committed through the breach of international law by the British under which they claimed Australia as 'terra nullius' and hence ignored the sovereignty of the original inhabitants and their property laws. The violence that unfolded in many areas throughout Australia resulted from the lack of respect for the sovereignty of the countries throughout the nation" (Sherwood, 2010, p. 17). Sherwood criticises settler-colonial cultural, legal and political hegemony, which has systematically marginalised Aboriginal and Torres Strait Islander peoples and their epistemologies, ontologies and axiologies (Sherwood, 2010).

Sovereignty carries a number of different meanings depending on the context in which it is used, and has several interdependent elements; for example, sovereignty is conceptualised as being reciprocal, meaning that independent state bodies recognise the status of neighbouring bodies to govern themselves within their territorial geographies without foreign interference (Krasner, 1999). This reality has seen the development of treaties between First Nations peoples and governments in settlercolonial countries across the globe. Sovereignty can also be thought of as the legitimised system of authority claimed by a nation to govern itself and determine who is and who is not part of the nation. Indigenous sovereignty is intrinsic to Indigenous people. However, they are frequently forced to claim their nationhood and define who belongs to their communities, in response to the imposition of settler sovereignty, which is violently overlaid by illegitimate governments, on the unceded territories to which Indigenous people belong. In this way, the occupation of a territory by Indigenous peoples prior to European invasion challenges the settler-colonial status quo, as the violation of Indigenous sovereignty through the forced imposition of European sovereignty brings into question the legitimacy of the nation-state. This reality has resulted in the need for agreement-making between Indigenous people and the state, and structural reform to address the inequalities in health, access to education, rates of incarceration and high rates of poverty experienced by Indigenous people.

In the Australian context, Moreton-Robinson (2015) explains the dismissal of Indigenous sovereignty by the British Empire as the result of a logic of possession, which continues to function as the rationale for the Australian settler-state's illegitimate sovereignty. Having emerged from a number of European treaties in the Peace of Westphalia during the mid-seventeenth century, European sovereignty established the principle of a nation-state by linking sovereignty to the right to a specific geographical territory. Accordingly, sovereignty became deeply connected to a nation's geographic boundaries, creating an understanding of "insider" and "outsider" members of the limited community (Anderson, 1983). Moreton-Robinson argues that a racialised logic of possession was deeply embedded in the regulation of non-white entry into Australia through the White Australia Policy (Moreton-Robinson, 2015). Reflecting Canada and New Zealand's Immigration Acts that gave preferential treatment to European immigrants, the US was also determined to ensure that the English language settler-state would be controlled by and for those of European heritage, which it did through the Naturalisation Act of 1790 (Moreton-Robinson, 2015). In this context, 
Moreton-Robinson suggests that the development of these regulatory mechanisms is indicative of the "inextricable connections between white possessive logics, race, and the foundation of nation-states" in settler-colonial societies (2015, p. 13). Having survived the impact of frontier violence, ongoing dispossession and formal attempts to assimilate Indigenous populations, Moreton-Robinson argues that Indigenous sovereignty exists within the urban metropolises of Sydney, New York, Toronto and Auckland, where Indigenous people maintain ongoing ontological relationships to their lands, regardless of the presence of a "modernity" that seeks to render them invisible (Moreton-Robinson, 2015).

Non-Indigenous scholars writing about Indigenous sovereignty frequently fall into the trap of identifying the various tensions, contradictions and difficulties that arise when Indigenous sovereignty is claimed, or recognised, in a legal context, and conclude that the recognition of Indigenous sovereignty is naïve, idealistic or untenable. This misunderstanding emerges from confusing Indigenous sovereignty, with bundles of rights given to a people by the state. Rather, Indigenous sovereignty exists whether the state recognises it or not. Fairbanks (1995) fails to recognise that Indigenous sovereignty exists outside of the normative legal frameworks of the American settler-colonial system, which reveals the limitations of settler-colonial approaches to understanding Indigenous sovereignty. Through his argument that sovereignty is only legitimate when a body is willing and able to exercise the executive power of a government over a sufficient population and adequate land base, Fairbanks (1995) views Indigenous sovereignty through a western worldview, and determines that Native American tribal governments retain only a limited form of sovereignty, if any at all. An emphasis on the settler-colonial legal mechanisms which recognise Native American sovereignty leads Fairbanks to conclude that Native American sovereignty not only is limited in scope but can technically be eliminated by the United States Congress (Fairbanks, 1995). He suggests that Indigenous sovereignty is an illusion because Native American peoples will always be dependent on the settler-state, and takes the cynical view that "whether Native American peoples, and their governments, are sufficiently resilient to survive even another generation or so remains to be seen" (Fairbanks, 1995, p. 149). In contrast, Indigenous sovereignty which is intrinsic to Indigenous people and the lands to which they belong highlights the illusion of settler sovereignty which has been manufactured without the consent of those whose lands have been colonised. Indigenous scholars working in this field are not so willing to dismiss sovereignty as a modality for resistance, resurgence, and the maintenance of Indigenous cultural and national identities.

In response to settler-colonial attempts to render Aboriginal people invisible, Watson (2009) invokes the notion of the "unsettled native" to frame the consequences of British denials of Indigenous sovereignty. Operationalised through the legal fiction of terra nullius, James Cook dismissed the sovereignty of Aboriginal and Torres Strait Islander peoples in 1770, beginning a process that would attempt to render Aboriginal people as homeless and property-less in their own lands (Watson, 2009). In spite of settler-state acts which have sought to erase Aboriginal laws and national identities, Watson highlights the fringe spaces in modern Australia that Aboriginal people have occupied, such as the Canberra Aboriginal Tent Embassy and other symbolic spaces 
of resistance, that represent the intrinsic quality of Indigenous sovereignty. The Tent Embassy has been a space of resistance to settler-colonialism in the struggle for Aboriginal land rights since its establishment in 1972, and symbolises the tension between the settler-state and Indigenous sovereignty, through the maintenance of a sacred fire, continued Indigenous occupation and the word "sovereignty" displayed on the lawns of Old Parliament House; bringing into sharp relief "the illusion of the free, informed, and consenting native's participation in the colonial project" (Watson, 2015, p. 30). The erasure of Indigenous sovereignty in the policies, public spaces and curricula of education institutions such as universities has emerged within a broader contest over whose national identities are deemed to hold legitimate authority.

In contrast to Fairbanks' dismissal of Indigenous sovereignty as a naïve political strategy in advancing Native American self-determination, O'Brien (2018) argues that tino rangatiratanga, Māori sovereignty, has played a tangible role in public consciousness in Aotearoa New Zealand, linked to the ways in which that sovereignty has been negotiated between Māori people and the settler-state. In response to the subjugation of Māori people by settler-colonial governments, the notion of "political entrepreneurship" is conceptualised by Māori academics as a powerful means for drawing on Māori tribal identities to mobilise political support, advance rights claims, and bring together Māori communities in ways that support the sociocultural spaces they occupy (O'Brien, 2018). With the Treaty of Waitangi, and the recognition of Māori as a national language, and a distinct colonial history, tino rangatiratanga animates politics in Aotearoa New Zealand political arenas in ways that they do not in the US. However, we can see similarities in instances where Māori sovereignty is constrained by settler-colonial pragmatism and threatened by dominating settlercolonial regimes that are determined not to relinquish power over the territory they colonised.

In reference to the numerous treaties signed by Native American peoples and the US government, scholars Alfred and Tomkins (2010) argue that the forces which produce high rates of poverty, violence and alcoholism within Indigenous communities in North America have emerged from a spiritual crisis caused by the dispossession of those peoples from their lands. As a result of the imposition of European power over First Nations peoples in Canada, Alfred and Tomkins reject the need for Indigenous sovereignty to be recognised by the government; instead of arguing for a "regeneration" approach that emphasises resistance, cultural strengthening and self-determination (2010, p. 4). Alfred and Tomkins insist that First Nations peoples should be wary of the settler-state which has rewritten histories, created systems that justify colonial rule, and maintained control over Indigenous people through deliberate attempts to cause them to "forget who they are" (Alfred \& Tomkins, 2010). Instead, they suggest that self-determination can become the "physical manifestation of nationhood; it is about (re)constructing individual, collective and social identities in ways that reflect Indigenous values and teachings" (Alfred \& Tomkins, 2010 , p. 6). In this way, the ongoing practice of culture at the local level, which is not contingent on formal recognition of heritage, identity or political status by the settler-state, becomes the most authentic means though which to live as Indigenous people (Alfred \& Tomkins, 2010). This supports the argument that Indigenous 
sovereignty is intrinsic to Indigenous people and the lands to which they belong. That sovereignty exists whether or not the settler-state acknowledges it and is grounded in the lived realities of Indigenous people and their relationships to environment and one another.

\section{The Right to Self-Determination}

The existence of Indigenous sovereignty has major social and political implications for modern settler-colonial countries. The United Nations (UN) Declaration on the Rights of Indigenous Peoples (UNDRIP) has come to represent the minimum standard for the treatment of Indigenous people. However, it features a major omissionthe acknowledgement of Indigenous sovereignty. In 2007, the UN General Assembly adopted the UNDRIP by a majority of 144 states in favour and four against. There were 11 abstentions; and the four most socially and economically prosperous settlercolonial countries, Australia, New Zealand, US and Canada, were the only objectors, citing concerns about potential implications for the undermining of the sovereignty and legal systems of the settler-state. Former Australian Federal Indigenous Affairs Minister Mal Brough spoke out against the adoption of UNDRIP, claiming that "there should only be one law for all Australians, and we should not enshrine in law practices that are not acceptable in the modern world." Similarly, in a tone that was dismissive of the empowering nature of the Declaration, for Indigenous people, New South Wales Liberal Senator Marise Payne claimed that "they seem, to many readers, to require the recognition of Indigenous rights to lands which are now lawfully owned by other citizens, both Indigenous and non-Indigenous, and therefore to have some quite significant potential to impact on the rights of third parties." Despite opposition from conservatives and the non-binding status of the Declaration within international law, since 2007 the four objecting states have turned their votes around, and UNDRIP has come to represent a significant standard for the treatment of Indigenous people around the world.

UNDRIP is central to the human rights tensions contained in cultural competence philosophy and praxis. International recognition of Indigenous self-determination was a major achievement. The Declaration recognises Indigenous people's right to control their own affairs through freedom from discrimination, and the right to meaningful participation with the state in decision-making. The Declaration provides important language to frame the goals and aspirations of Indigenous people within international legal frameworks and goes a significant way in recognising the political legitimacy of Indigenous decision-making. It also includes the requirement of states to cooperate in good faith with Indigenous people to obtain their free, prior and informed consent when adopting legislative measures which may affect them (Article 19). Article 19 contains what are arguably the most useful lines in the Declaration for Indigenous people in asserting their sovereignty, and reflects ethical tensions which go to the heart of settler-states; for example, the questionable legitimacy of settlerstates through their failure to obtain free, prior and informed consent in the occupation 
of Indigenous territories. The following Articles contained in the Declaration outline the right to Indigenous self-determination and represent the minimum standard of the treatment of Indigenous people by their respective states (UNDRIP, 2007):

Article 4: Indigenous peoples, in exercising their right to self-determination, have the right to autonomy or self-government in matters relating to their internal and local affairs, as well as ways and means for financing their autonomous functions.

Article 5: Indigenous peoples have the right to maintain and strengthen their distinct political, legal, economic, social and cultural institutions, while retaining their right to participate fully, if they so choose, in the political, economic, social and cultural life of the State.

Article 18: Indigenous peoples have the right to participate in decision-making in matters which would affect their rights, through representatives chosen by themselves in accordance with their own procedures, as well as to maintain and develop their own Indigenous decisionmaking institutions.

Article 19: States shall consult and cooperate in good faith with the Indigenous peoples concerned through their own representative institutions in order to obtain their free, prior and informed consent before adopting and implementing legislative or administrative measures that may affect them.

The existence of Indigenous sovereignty is the driving force in the creation of this core human rights instrument, and while the inclusion of the right to free, prior and informed consent is significant in the advancement of Indigenous rights, the failure of states to recognise Indigenous sovereignty has resulted in a document that falls short of reflecting the truth of settler-colonial ethical obligations. The adoption of UNDRIP by the UN General Assembly in 2007 was the culmination of decades of drafting, advocacy, negotiations and appeals to states and the international human rights community by Indigenous people and non-Indigenous allies. It was a landmark achievement, particularly through the unequivocal recognition of Indigenous people's right to self-determination (Cowan, 2013). However, persistent claims by Indigenous people framed around sovereignty have been met with sustained opposition from states whose concerns centre on the potential fragmentation of their territorial integrity, leading to the formation of new micro-states (Cowan, 2013). In opposition to these concerns, Cowan argues that "the professed fear of states is disproportionate to the actual threat to their sovereignty .... Simply asserting the right to self-determination does not mean sovereign independence would always be preferred. The goal is almost always self-determination alongside the other people sharing the same state: interdependence rather than independence" (Cowan, 2013, p. 268).

\section{National Identity and Cultural Competence}

Higher education institutions are social products that cannot be separated from the specific historical contexts from which they emerge (Seddon, 2001). In Australia, Aboriginal and Torres Strait Islander peoples have experienced frontier violence, dispossession, exclusion from education systems, and assimilation through the 
reproduction of settler-colonial epistemological traditions that marginalise IKs in systems of education (Ball, 2004; Denis, 2011; Hickling-Hudson \& Ahlquist, 2003; McMurchy-Pilkington, Pikiao, \& Rongomai, 2008; Russell-Mundine, 2016). Persistent omissions of Indigenous cultures, histories and languages in Australian higher education have been attributed to a range of factors embedded within universities, including the privileging of European epistemologies, ontologies and axiologies, and failing to attract, support, retain and promote Indigenous staff and students (RussellMundine, 2016; Wolfe, 2006). In response to this reality, the integration of cultural competence within Australian higher education has been accompanied by calls for "recognition of our First Nation's people sovereignty and current circumstances resulting from invasion and ongoing colonisation" as well as to "respect and recognise Indigenous Knowledges" in the academy (Sherwood \& Russell-Mundine, 2017, p. 138).

In the case of Australia, New Zealand, Canada and the US, colonisation is not merely a process but a dominant power structure that violently supplants Indigenous communities with a new colonial society on the expropriated land (Wolfe, 2006). Given this reality, educational institutions are "cultural constructions grounded in the worldviews, beliefs, and norms of those who conceptualise and teach the curricula," and therefore cannot be separated from the colonial contexts from which they emerge (Ball, 2004, p. 456; Seddon, 2001). In light of this, the provision of higher education is a significant space of contest for the settler-state, in the ongoing omission of Indigenous sovereignty through significant distortions of the past (Seddon, 2001). Responding to the powerful regulatory technology of education, Indigenous people have developed modes of resistance to "the logic of elimination" that is integral to the settler-colonial project, producing unstable, contested relationships of power within Australian universities (Wolfe, 2006, p. 391).

The development of higher education institutions in Australia has been shaped by the conflict over representations of the colonial past. Ranging from indifference to frontier violence, assimilation, protection and segregation, to reconciliation, successive Australian governments have sought to privilege western norms in universities; relegating Indigenous identities, knowledge, histories and cultures to stereotypical ancient imaginings, including representations of Aboriginal people as an appropriate study of "stone age man" at the "threshold of history" (Clark in Parkes, 2007, p. 386). Taken up by the Howard Liberal government in 2006 as a renewal of content relating to Australian identity, curriculum design has been a space where colonising practices are both reproduced and resisted (Parkes, 2007). Known as the History Wars, the consolidation of national identity by some Australian conservatives has ignored a long history of colonial violence and Aboriginal resistance, instead of solidifying the cultural myth that Australia was relatively peacefully settled, with Aboriginal lives having been lost as an unintended consequence of exposure to European diseases in the early colonial period (Clark, 2008). The History Wars were framed by writers such as Geoffrey Blainey as a triumphalist celebration of the achievements of socalled "settlement," including the bringing about of western civilisation, technological developments and liberal democracy to the Australian continent (Parkes, 2007, p. 388). 
In response to systemic Indigenous disadvantage, UA has called for the Indigenisation of higher education, as a central element in the adoption of cultural competence philosophy and praxis, in a way that "incorporates the in-depth study of unique elements of contemporary life in Indigenous communities, such as the protection of land rights, subsistence, sovereignty and self-determination" (UA, 2011). In order to understand Australian higher education institutions as spaces that have the power to erase or highlight Indigenous sovereignty, it is important to examine the origins of national identity which have become embedded in every aspect of settler-colonial society, including educational institutions. Anderson (1983) defines the nation as "an imagined political community — and imagined as both inherently limited and sovereign" (p. 6).

A nation is thought of as "imagined" because individuals will never meet, let alone come to know every other member of the nation, and yet can be confident in their "steady, anonymous, simultaneous activity" across time and geographic space (Anderson, 1983, p. 26). The nation is thought of as a "community" as there is a "deep horizontal comradeship" that connects members of a nation even in the presence of stark inequalities between groups and individuals (Anderson, 1983, p. 7). Nations are thought of as "limited" because they are constrained by distinct political boundaries that regulate how much territory the nation can occupy because, according to Anderson, multiple nations cannot share the same political jurisdiction (Anderson, 1983). Finally, a nation is thought of as "sovereign" because the concept was produced by European societies at a time when the old, divinely ordained dynastic realms were being dismantled by revolutionary Enlightenment Secularism (Anderson, 1983, p. 7). In this sense, Indigenous national identities, such as the Wiradjuri Nation (New South Wales, Australia) or the Great Sioux Nation (South Dakota, US)_-defined by their own languages, cultures and particular geographic boundaries-present a significant problem for the settler-state, as they undermine the political legitimacy of the nation.

Anderson's observations on the development of national identities as imagined political communities, in which people perceive themselves as a homogenous body connected across time and geography, provide several ways for understanding how national identities are created and their implications for individuals within those imagined communities (Anderson, 1983). Following the decline in monarchies and dynastic rule across Western Europe, the emergence of print media that disseminated information about world events, within specific political boundaries, allowed for each individual within that jurisdiction to share the same experiences simultaneously (Anderson, 1983). The convergence of the printing press and capitalist economies was a catalyst for the standardised languages that gave rise to national imaginings that responded to the limitations of mortality "by transforming fatality into continuity" (Anderson, 1983, p. 11). By no means exclusive to the nation-states of western Europe, continuity is a core component of Anderson's (1983) theory of national identity. From the settler-colonial ontological perspective, prior to the age of vernacular print media, religion was the primary category by which people imagined themselves to be part of a community that existed beyond the life span of the individual (Anderson, 1983). However, this changed dramatically with the advent of the industrial revolution, which saw an explosion in systems of production, powerful new 
communication technologies and the stabilisation of languages-of-state (Anderson, 1983). In this way, the emergence of nationalism in Europe during the eighteenth century was not simply the awakening of nations to self-consciousness, but the intentional construction of a secular political community with a common language, located in a limited geographical jurisdiction (Anderson, 1983). Tension arises when we consider how these early European nations were conceptualised as sovereign, while the imagined political communities of Indigenous people were not.

While the concept of a nation was imagined to be sovereign as a means of breaking away from classic religious communities that dominated the West prior to European capitalism, secular education publicly available to all citizens has seen the construction of a shared identity among a nation and its people. Higher education, therefore, can be seen as a powerful space in the nation-building projects of settler-states, through the social reproduction of national identities in teaching and learning which shapes the values of the nation (Seddon, 2001). An ethical problem arises, however, when settler-colonial education institutions fail to recognise the sovereignty, histories, cultures, languages and national identities of Indigenous people within their teaching and learning. A central aspect of Anderson's theory of national identity is the role of newspapers, radio and television in facilitating the shared experience of world events, as part of the simultaneous lived realities of members of a given nation (Anderson, 1983). Although he was writing at a time when easily accessible high-speed internet now available to most people at a moment's notice had not yet been realised, Anderson's theory remains useful for analysing the power of higher education for constructing a shared pool of narratives drawn from the lived experiences of settler-colonists (Anderson, 1983). Parkes argues that the power of education should not be underestimated, given its utility for "linking the development of the individual to the images and narratives of nationhood" (Parkes, 2007, p. 384). By ignoring Indigenous sovereignty and Aboriginal and Torres Strait Islander peoples' ways of knowing, higher education plays an active role in the maintenance of settlercolonial dominance, solidifying the Australian nation-state in the imagination of the individual (Anderson, 1983).

The recognition of Indigenous sovereignty is a key element in the process of interrogating higher education in settler-colonial countries, as Indigenous people have historically been excluded from institutions which have determined whose knowledge is valued and what skills should be taught. Hickling-Hudson and Ahlquist (2003) frame their critique of settler-colonial education by highlighting commonalities that exist between techniques of eroding Indigenous sovereignty, such as the forced removal of Aboriginal children from their families, Native American boarding schools, and the identification of the unique social positioning of Indigenous people in the settler-state (Hickling-Hudson \& Ahlquist, 2003, p. 66). Through an exploration of white dominance and the erasure of Indigenous cultures within national memories, enacted by omissions in systems of education, scholars identify the need to build anti-racist alliances across ethnic, racial and cultural boundaries, that privilege Indigenous cultures and histories (Hickling-Hudson \& Ahlquist, 2003). As a foundation for redistributing power along more equitable lines, it is argued that anti-racist alliances are created not to elicit a sense of guilt within non-Indigenous 
people, but to highlight the ways that ongoing colonisation is operationalised through education systems that determine which cultural memories are worth preserving and which should be forgotten (Hickling-Hudson \& Ahlquist, 2003). This is core to the work of embedding cultural competence in higher education.

Universities have been sites of conflict between Indigenous and non-Indigenous people in shaping perceptions of citizens through the way the past is represented (Seddon, 2001). Decisions made by University faculties, schools and departments are intimately tied to the logic of settler-colonial hegemony in determining what should be taught and how knowledge should be transferred across generations (Seddon, 2001). In favour of Indigenous voices and histories which have been excluded from higher education for the majority of the life of the nation, Parkes argues that over the past several decades, education has been a "battlefield in a war over the decentering of Europe" as the main point of reference for Australian national identity (Parkes, 2007, p. 384). Parkes discusses attitudinal changes in Australian education during the 1990s which emphasised the negative impacts of colonisation on Aboriginal societies. This resulted in some public commentators responding that the nation's past was being held hostage by partisan operatives with the intention of "infecting student's minds through the use of politically correct buzzwords that included terms like invasion, genocide, dispossession, Aboriginality and terra nullius" (Parkes, 2007, p. 388). In this way, higher education works not simply as a vehicle for the didactic transferral of knowledge from lecturer to student, but as a tool of colonial power in the production of collective national self-conceptions tied to a colonial imagination (Anderson, 1983).

Emerging from the relationship between Indigenous people and the settlerstate, the development and implementation of cultural competence in Australian higher education raise significant questions relating to the recognition of Indigenous sovereignty and the need to support Indigenous self-determination as a result. The notion of an imagined community is a useful framing device for analysing the concept of national identity in modern countries that have superimposed Eurocentric colonial imaginings on top of pre-existing Indigenous societies. Anderson (1983) thinks of national identity as the deliberate construction of shared narratives, through which people perceive themselves as part of a distinct political community beyond the lifespan of the individual, despite having never met each member of that community (Anderson, 1983). What then, are institutions of higher learning, if not significant public spaces in the reproduction of settler-colonial identities and knowledge? In the context of competing national identities within a modern nation-state, Anderson argues that while nationhood carries the highest form of universally understood political legitimacy, many old nations once thought to be fully consolidated are being challenged by "sub-nationalisms" within their own borders (Anderson, 1983, p. 3). In Australia, this is being driven by and has significant implications for, Indigenous people whose sovereignty continues to be ignored in important public spaces, such as universities that reflect and maintain settler-colonial power, narratives and values. 


\section{Conclusion}

Throughout this chapter, I have attempted to argue that the provision of Australian higher education can be a powerful tool for the maintenance of the settler-colonial status quo. Literature on the relationship between settler-states and Indigenous peoples has highlighted some important concepts relating to the need to recognise Indigenous sovereignty. There is a need for Indigenous students to see their cultures referenced throughout their learning and the recognition of Indigenous sovereignty in cultural competence philosophy and praxis should guide stakeholders working in this field. There seems to be a general sense in the literature that the dominant national identities which have formed in English language settler-colonial nations default to a Eurocentric view of the world when it comes to thinking about the construction and distribution of knowledge in society. A process of de-centering Europe as the main point of reference for knowledge and national identities could assist in the reconstruction of institutions of higher learning that value Indigenous "ways of knowing, being and doing" (Sherwood, 2010). Indigenous sovereignty acted out through resistance to settler-colonialism should take centre stage through rights discourses in higher education as Indigenous people experience ongoing structural inequality since the imposition of European sovereignty on their countries. Therefore, the co-generation of knowledge that balance Indigenous worldviews with western ways of doing emerges as one possible solution for providing Indigenous and non-Indigenous students opportunities to engage with the complexity of settlercolonial life. The recognition of Indigenous sovereignty in the provision of education in settler-colonial countries has been shown to produce a more "ecological process of education that allows Indigenous people to become agents of transformation in their own social and cultural contexts" (McMurchy-Pilkington et al., 2008, p. 633). Australian universities must recognise Indigenous sovereignty throughout cultural competence philosophy and praxis and approach the co-generation of knowledge in higher education through intentional challenges to settler-colonial institutions that perpetuate Indigenous disadvantage.

\section{References}

Anderson, B. (1983). Imagined Communities: Reflections on the Origin and Spread of Nationalism. London: Verso Books.

Alfred, T., \& Tomkins, E. M. (2010, August). The politics of recognition: A colonial groundhog day. Discussion paper prepared for Chiefs of Ontario. Chiefs of Ontario, Canada: Assembly of First Nations.

Battiste, M. (2005). Indigenous knowledge: Foundations for first nations. World Indigenous Nations Higher Education Consortium-WINHEC Journal, 1-12.

Ball, J. (2004). As if Indigenous knowledge and communities mattered: Transformative education in First Nations communities in Canada. American Indian Quarterly, 454-479. 
Clark, A. (2008). History's children: History wars in the classroom. UNSW Press.

Cowan, A. (2013). UNDRIP and the intervention: Indigenous self-determination, participation, and racial discrimination in the northern territory of Australia. Pacific Rim Law \& Policy Journal, 22, 247.

Cross, T. L., Bazron, B. J., Dennis, K. W. \& Isaacs, M. R. (1989). Towards a culturally competent system of care: a monograph on effective services for minority children who are severely emotionally disturbed. Washington, DC: Child and Adolescent Service System Program Technical Assistance Center, Georgetown University Child Development Center.

Fairbanks, R. A. (1995). Native American sovereignty and treaty rights: Are they historical illusions. American Indian Law Review, 20, 141.

Hickling-Hudson, A., \& Ahlquist, R. (2003). Contesting the curriculum in the schooling of Indigenous children in Australia and the United States: From Eurocentrism to culturally powerful pedagogies. Comparative Education Review, 47(1), 64-89.

Hinkson, M., \& Harris, A. (2010). Aboriginal Sydney: A guide to important places of the past and present Second edition. Aboriginal Studies Press.

Krasner, S. D. (1999). Sovereignty: Organized Hypocrisy. Princeton: Princeton University Press.

Moreton-Robinson, A. (2015). The white possessive: Property, power, and indigenous sovereignty. University of Minnesota Press.

McMurchy-Pilkington, C., Pikiao, N., \& Rongomai, N. (2008). Indigenous people: Emancipatory possibilities in curriculum development. Canadian Journal of Education/Revue canadienne de l'éducation, 614-638.

O'Brien, T. (2018). Political entrepreneurship in the field of Māori sovereignty in Aotearoa New Zealand. The British Journal of Sociology.

Parkes, R. J. (2007). Reading History curriculum as postcolonial text: Towards a curricular response to the history wars in Australia and beyond. Curriculum Inquiry, 37(4), 383-400.

Rigney, L. I. (2017). A design and evaluation framework for Indigenisation of Australian universities. In J. Frawley, S. Larkin, \& J. A. Smith (Eds.), Indigenous Pathways, Transitions and Participation in Higher Education (pp. 45-63). Singapore: Springer Open.

Rigney, L. I. (1999). Internationalization of an Indigenous anticolonial cultural critique of research methodologies: A guide to Indigenist research methodology and its principles. Wicazo sa review, 14(2), 109-121.

Riley, L., Howard-Wagner, D., Mooney, J., \& Kutay, C. (2013). Embedding Aboriginal cultural knowledge in curriculum at university level through Aboriginal community engagement. In Seeding success in Indigenous Australian higher education, 251-276. Emerald Group Publishing Limited.

Russell-Mundine, G., \& Mundine, G. (2016). Daring to speak the truth: De-constructing and reconstructing reconciliation. Journal of Indigenous Wellbeing, 1(1), 83-96.

Seddon, T. (2001). National curriculum in Australia? A matter of politics, powerful knowledge and the regulation of learning. Pedagogy Culture and Society, 9(3), 307-331.

Denis, V. (2011). Silencing Aboriginal curricular content and perspectives through multiculturalism: "There are other children here." Review of education, pedagogy, and cultural studies, 33(4), 306-317.

Sherwood, J., \& Russell-Mundine, G. (2017). How we do business: Setting the agenda for cultural competence at The University of Sydney. In J. Frawley, S. Larkin, \& J. A. Smith (Eds.), Indigenous Pathways, Transitions and Participation in Higher Education (pp. 133-150). Singapore: Springer Open.

Sherwood, J. (2010). Do No Harm: Decolonising Aboriginal Health Research. Sydney: University of New South Wales.

Sherwood, J., Keenan, T., Kelly, B., \& Keech, S. (2011). Indigenous Studies: Teaching and Learning Together. Two Way Teaching and Learning: Towards culturally reflective and relevant education.

The University of Sydney. (2012). Wingara Mura-Bunga Barrabugu: The University of Sydney Aboriginal and Torres Strait Islander Integrated Strategy. Retrieved from https://sydney.edu.au/ strategy/docs/wingara-mura-bunga-barrabugu.pdf. 
United Nations General Assembly. (2007). United Nations declaration on the rights of indigenous peoples. UN Wash, 12, 1-18.

United Nations General Assembly. (1948). Universal declaration of human rights. UN General Assembly, 302(2).

Universities Australia. (2011). National Best Practice Framework for Cultural Competency in Australian Universities. Canberra: Universities Australia.

Watson, I. (2009). Sovereign spaces, caring for country, and the homeless position of Aboriginal peoples. South Atlantic Quarterly, 108(1), 27-51.

Wolfe, P. (2006) Settler colonialism and the elimination of the native. Journal of Genocide Research, $8(4), 387-409$.

Michael Johnston is an accredited secondary school teacher in New South Wales. He is a nonAboriginal person who has pursued education as one means by which to address settler-colonial historical injustice. He has co-led cultural competence workshops at the National Centre for Cultural Competence, and in 2018, he completed a Master of Human Rights at The University of Sydney. Michael currently resides in the Northern Territory, supporting Aboriginal selfdetermination at local government level.

Open Access This chapter is licensed under the terms of the Creative Commons Attribution 4.0 International License (http://creativecommons.org/licenses/by/4.0/), which permits use, sharing, adaptation, distribution and reproduction in any medium or format, as long as you give appropriate credit to the original author(s) and the source, provide a link to the Creative Commons license and indicate if changes were made.

The images or other third party material in this chapter are included in the chapter's Creative Commons license, unless indicated otherwise in a credit line to the material. If material is not included in the chapter's Creative Commons license and your intended use is not permitted by statutory regulation or exceeds the permitted use, you will need to obtain permission directly from the copyright holder.

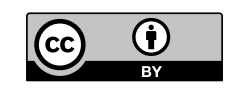

